\title{
ROMANCES NOS CATÁLOGOS DE PIERRE BONNARDEL
}

\author{
Gabriela Antunes Marques*; Profa. Dra. Márcia Azevedo de Abreu.
}

\section{Resumo}

Os catálogos de gabinetes são indícios que permitem a percepção do movimento de livros, livreiros e leitores e o questionamento de algumas concepções dos estudos da Literatura. Nesse sentido, o presente trabalho busca levantar uma rápida discussão acerca de catálogos do Gabinete de Leitura de Pierre Bonnardel, em especial a questão da constante permanência de títulos.

\section{Palavras-chave:}

Catálogos de gabinetes ; Romances ; História da Leitura.

\section{Introdução}

Os gabinetes de leitura, estabelecimentos em que se liam e alugavam livros, foram locais muito ativos durante o século XIX. Em um momento em que o número de alfabetizados aumentava e o romance se popularizava, a predominante procura por obras de ficção nos Gabinetes aparece como "(...) uma estranha, silenciosa revolução"1. Como interessantes fontes primárias, os catálogos utilizados para divulgação dos títulos disponíveis em gabinetes para aluguel, bem como a organização dos mesmos, podem evidenciar livros em circulação e dar pistas do mercado editorial e da atividade de livreiroseditores durante o século XIX, contribuindo para o entendimento das mudanças do período que envolvem o mundo literário - como, por exemplo, indícios da circulação de romances entre países, uma das discussões do projeto temático $A$ circulação transatlântica dos impressos - a globalização da cultura no século XIX, de que as histórias literárias convencionais tendem a excluir da ficção oitocentista o aspecto transnacional, de influências recíprocas, em que gabinetes de leitura e escritores populares também fazem parte.

Com o objetivo de refletir sobre as questões apontadas relacionadas aos catálogos de gabinetes, este trabalho busca observar a constante presença diacrônica de algumas obras nos catálogos de Pierre Bonnardel, proprietário do primeiro gabinete de leitura em Portugal de que se sabe, fundado possivelmente entre1814/1815 e, a partir dessa observação, fazer breves inferências.

\section{Resultados e Discussão}

O cadastro de catálogos no CITRIM, banco de dados do projeto temático ao qual esse trabalho se relaciona, possibilitou a abordagem metodológica feita. As informações recolhidas são de quatro publicações, todas inteiramente em português: um catálogo de 1814, outro de 1815, um terceiro datado de 1848 que ao final apresenta uma lista de Novelas lançadas abrangendo o período de 1840 - 1847 e um suplemento de 1849. Os primeiros catálogos não apresentam, aparentemente, uma organização na apresentação dos títulos - não há ordem alfabética ou por nome/sobrenome de autor. Esses catálogos, de 1814 e 1815 são significativamente menores que o de 1848, apresentando 21 e 15 páginas, respectivamente, enquanto que o de 1848 tem ao total 118 páginas. Em 1814, embora livros de poesia e História Geral estejam presentes, a página inicial anuncia apenas
Novelas. Em 1815 ainda não há organização nos títulos, porém já há uma divisão interna entre Novelas, Livros de Instrução e Versos. No catálogo de 1848, essa divisão desaparece, não há ordem alfabética ou por autor que organize os títulos. Por outro lado, o suplemento de 1849, dedicado somente a romances, apresenta uma divisão por autores, com uma breve explicação sobre os mesmos ("De Paulo de Kock: novelas para rir") e uma organização alfabética nos títulos.

Cadastrando os romances presentes nesses catálogos e suplemento no CITRIM, foi possível a junção de informações na seguinte tabela:

Total de Romances

Não permanecem, aparecendo em apenas uma das publicações

Permanecem em duas publicações

Permanecem em três publicações

Permanecem nas quatro publicações

Tabela 1. Permanência de títulos ao longo dos quatro catálogos analisados

\section{Conclusões}

A breve pesquisa realizada e a tabela acerca do Gabinete de Leitura de Pierre Bonnardel pode trazer evidências próximas daquilo que $M_{0}{ }^{2}{ }^{2}$ apontou acerca de catálogos que circulavam no Brasil entre 1843 e 1865. A mesma lógica da constância e dinamismo, em que "sucessos de longa e média duração vinham mesclados com títulos atuais, gerando uma miscelânea capaz de agradar aos mais variados gostos. "“ também parece estar presente nos catálogos de Bonnardel. Muito provavelmente, essa estratégia de constância mas ao mesmo tempo dinamismo, com novidades sempre anunciadas, reflete os pedidos dos leitores da época, o que fez com que Bonnardel permanecesse ativo por um longo período e obtivesse sucesso, permitindo a publicação de longos catálogos impressos.

\section{Agradecimentos}

À Profa. Dra. Márcia Azevedo de Abreu, pela paciente orientação durante o trabalho realizado.

À Fapesp, pela bolsa concedida.

${ }^{1}$ ESTEVES, Rosa “ Gabinetes de Leitura em Portugal no século XIX (1815 1853" Revista da Universidade de Aveiro, ${ }^{\circ}$ 1, 1984, p. 216

2 MODENEZ, Julio Cesar "Por dentro dos livros: a presença de romances em catálogos de livreiros (1843 - 1865)” 2013 (Monografia) - Universidade Estadual de Campinas, Campinas

IIdem, p. 36 